\title{
Yam-Based Cropping Systems Performances with Herbaceous Legumes and Chemical Fertilizers
}

\author{
Raphiou Maliki ${ }^{1 *}$, Anne Floquet ${ }^{2}$, Romain Glèlè Kakaï ${ }^{3}$ and Brice Sinsin ${ }^{4}$ \\ ${ }^{1}$ Raphiou Maliki, PhD, National Institute of Agricultural Research of Benin (INRAB), Benin \\ ${ }^{2}$ Anne Floquet, Professor, Benin Center for Environment, Economic and Social Development (CEBEDES), Benin \\ ${ }^{3}$ Romain Glèlè Kakaï, Professor, Faculty of Agricultural Sciences of the University of Abomey-Calavi (FSA/UAC), Benin \\ ${ }^{4}$ Brice Sinsin, Professor, Faculty of Agricultural Sciences of the University of Abomey-Calavi (FSA/UAC), Benin
}

*Corresponding author: Raphiou Maliki, PhD, National Institute of Agricultural Research of Benin (INRAB), Calavi, Benin.

Received Date: October 05, 2019

Published Date: October 21, 2019

\begin{abstract}
In West Africa, the traditional yam-based cropping systems (shifting cultivation and slash-and-burn) contribute to the deforestation, land degradation and low soil productivity. With the aim of designing more sustainable yam cropping systems, the agronomic research organization in Benin implemented alternative systems including herbaceous legumes (Aeschynomene histrix and Mucuna pruriens var utilis) and chemical fertilizers. This study examines the effect of rotations with herbaceous legumes and chemical fertilizers on yam yields and soils, to see how consistent they are for the different farmers within a site, and different sites. A perennial experiment was implemented for 4 years, with 2-year rotations, smallholder farmers' traditional rotations maize-yam or 1-year Andropogonon gayanus (natural fallow)-yam, with rotations intercropped Aeschynomene histrix with maize-yam or intercropped Mucuna pruriens with maize and chemical fertilizers. The experiment was conducted with 32 farmers, eight in each site (Miniffi, Gomè, Akpéro and Gbanlin). For each of them, we used a randomized block design with four replicates and four crop rotation treatments. The same treatments didn't "work" for all 32 farmers from one year to another. The effects of treatments on yam yields differed significantly for the different farmers within a site, and different sites. Yam has a poor response to mineral fertilizer applications. When natural fallow and maize as precedents were compared, yam yield was higher after a (short) natural fallow, despite the chemical fertilizers supply on maize. Indeed, the decrease in yam yields was slower year after year after fertilized maize compared to natural fallow but yam yields remained the lowest after maize. Soil nitrogen and phosphorus concentrations were improved on different sites on yam-based cropping systems with herbaceous legumes and chemical fertilizers in $0-10 \mathrm{~cm}$ and $10-20 \mathrm{~cm}$ depth.
\end{abstract}

Keywords: Chemical fertilizers; Herbaceous legumes; Production; Soil fertility; Sustainable agriculture

\section{Introduction}

Yam (Dioscorea spp.) is a tuber crop widely cultivated in the humid and sub-humid lowland regions of West Africa and the Caribbean. More than $90 \%$ of the worldwide production ( 40 million metric tons of fresh tubers year-1) is produced in West Africa [1].

Yam cultivation in West Africa is now confronted with the scarcity of fertile soil available for clearing [2]. In Benin nowadays, farmers hardly have the possibility to rely on long duration fallow and yam is being cultivated in 1 or 2-year herbaceous fallow-yam or maize-yam rotation systems with manual incorporation of residue into the soil.

The decline in yam yields under continuous cultivation has led to the largely accepted conclusion that yam requires a high level of natural soil fertility (organic matter and nutrient) (O'Sullivan and Ernest, 2008). Since the demand for yam keeps increasing due to the continued population growth, reserves of arable land are diminishing, and fallow duration is decreasing. It is becoming necessary to sustainably increase yam productivity in sedentary cropping systems (O'Sullivan and Ernest, 2008) (Figure 1). There is a dire need therefore to assess in farmers' conditions the economic performance of sustainable cultivation techniques. Ongoing soil degradation could be reduced by the adoption of new farming techniques such as improved fallows of herbaceous legumes [3,4].

With the aim of designing more sustainable yam cropping systems, the agronomic research organization in Benin implemented alternative systems including herbaceous legumes, short natural 
fallow and maize plus chemical fertilizers. On the basis of the results of this on-farm research, yam-based systems including herbaceous legumes were diffused. A perennial experiment was implemented for 4 years, with 2-year rotations, smallholder farmers' traditional rotations maize-yam or 1-year Andropogonon gayanus fallow-yam, with rotations intercropped Aeschynomene histrix with maize-yam or intercropped Mucuna pruriens with maize.

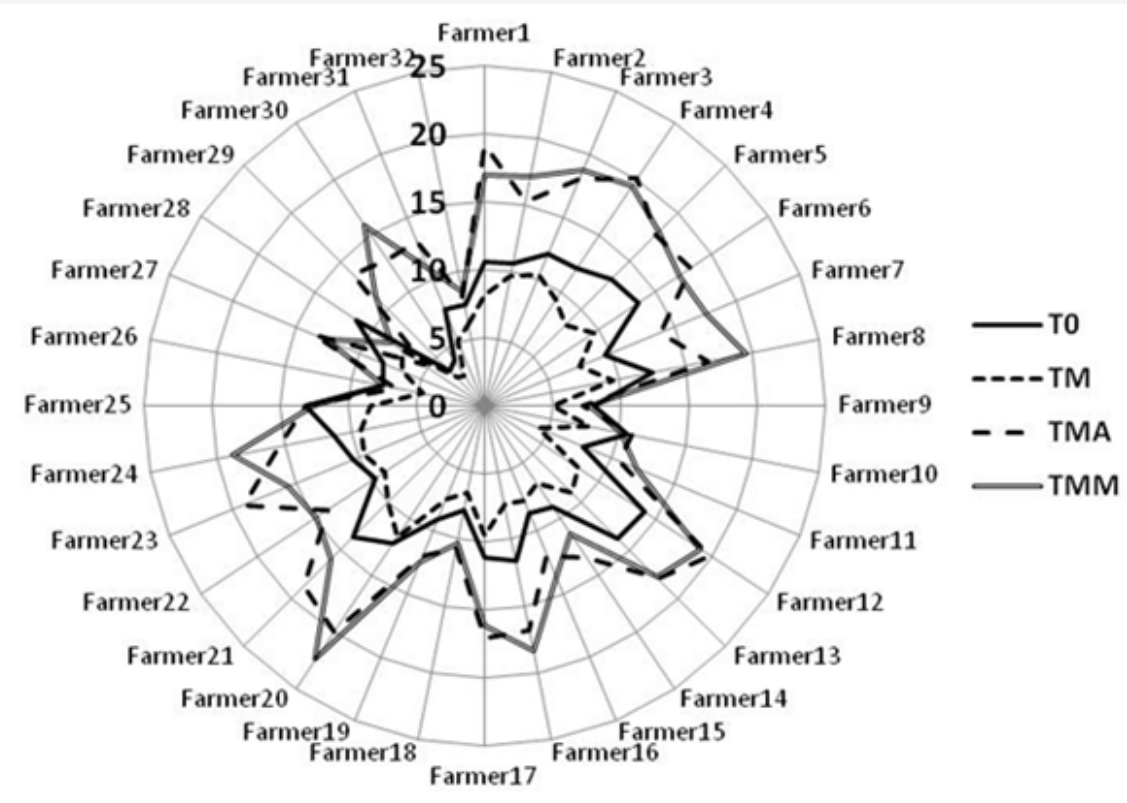

Figure 1: Effect of yam based-cropping systems on yam yield in the 2003 cropping season differed significantly by farmer for the same treatments.

Legend: T0 (control 1): 1-year fallow - yam rotation; TM (control 2): maize with chemical fertilizers - yam rotation; TMA: A. histrix /maize with chemical fertilizers intercropping - yam rotation; TMM: M. pruriens /maize with chemical fertilizers intercropping - yam rotation;

The objective of this study was to measure the effect of rotations with herbaceous legumes and chemical fertilizers on yam yields and soils, to see how consistent they are for the different farmers within a site, and different sites.

\section{Discussion}

The same treatments didn't "work" for all 32 farmers from one year to another. The effects of treatments on yam yields differed significantly for the different farmers within a site, and different sites. The heterogeneity of results should be related to the smallholders' individual effects and practices. If they don't work for some farmers, then is it obvious that those were farmers with relatively poor soil, or who planted late or... In fact crop management (weeding, crop duration, crop density...), site specific conditions (soil organic matter, soil macronutrients, including cumulative amount of rainfall in the 6th month of the yam growing period) could affect yam production [2]. When natural fallow and maize as precedents were compared, yam yield was higher after a (short) natural fallow, despite the chemical fertilizers supply on maize. Indeed, the decrease in yam yields was slower year after year after fertilized maize compared to natural fallow but yam yields remained the lowest after maize (Figure 2). This low residual effect of fertilizers on yam is in accordance with farmers beliefs that yam has a poor response to mineral fertilizer applications as well as with the few experiments conducted on this topic in Benin. Under similar conditions to the present research (rainfall, kokoro landrace), Srivastava, Dagbenonbakin and Gaiser [5] did not find any significant response to mineral fertilizer nor to manure applications on yam cultivated in the central part of Benin (low land use intensity). Gbedolo [6] also reported that experimentation with mineral fertilizers on Benin rarely produced significant results, and that $\mathrm{N}$ application resulted in tubers of low organoleptic quality. Similar lack of response was found in both forest transition and savannah areas in Nigeria after application of a range of mineral and organic fertilizers (Ajayi, Akinrinde and Asiedu 2006). However, many experiments concluded otherwise. In Ghana in a forest transition zone where farmers typically plant yam on newly cleared fields, fertilizer applied in several splits did increase tuber yields by $22 \%$ without reducing the sensory quality of the product [7]. In Trinidad, Chapman (1965) obtained a 30\% increase in tuber yield, under the condition that $\mathrm{N}$ application was delayed until three months after planting. Several other works showed positive effects of mineral fertilizers on yam yield [8,9]. Diby et al. [10] in Ivory Coast came to the conclusion that response to fertilizers of both D. alata, D. cayenensis-rotundata are affected by soil properties. Fertilizer application increased dry matter (DM) production of both species in the savannah site but not in the forest site. Diby et al. [2] also showed that the low yields obtained on soils with low organic matter content were not improved by supplying mineral fertilizer. This would lead to the hypothesis that there are forests soils too rich and savanna soils too poor in organic matter for any response to chemical fertilizers and in between a range of moderately depleted soils where a response can be expected. In the end, the effects of fertilizer supply on yam have to be related to soil organic 
matter contents and boundary conditions (climate, agro-ecological zone, soil type, cultivation history) as well as to the fertilizer type supplied and its application and to the crop management practices
[11]. In all, little research has been conducted so far to interpret the response to fertilizers either applied on yam or here on a precedent crop (Table 1).

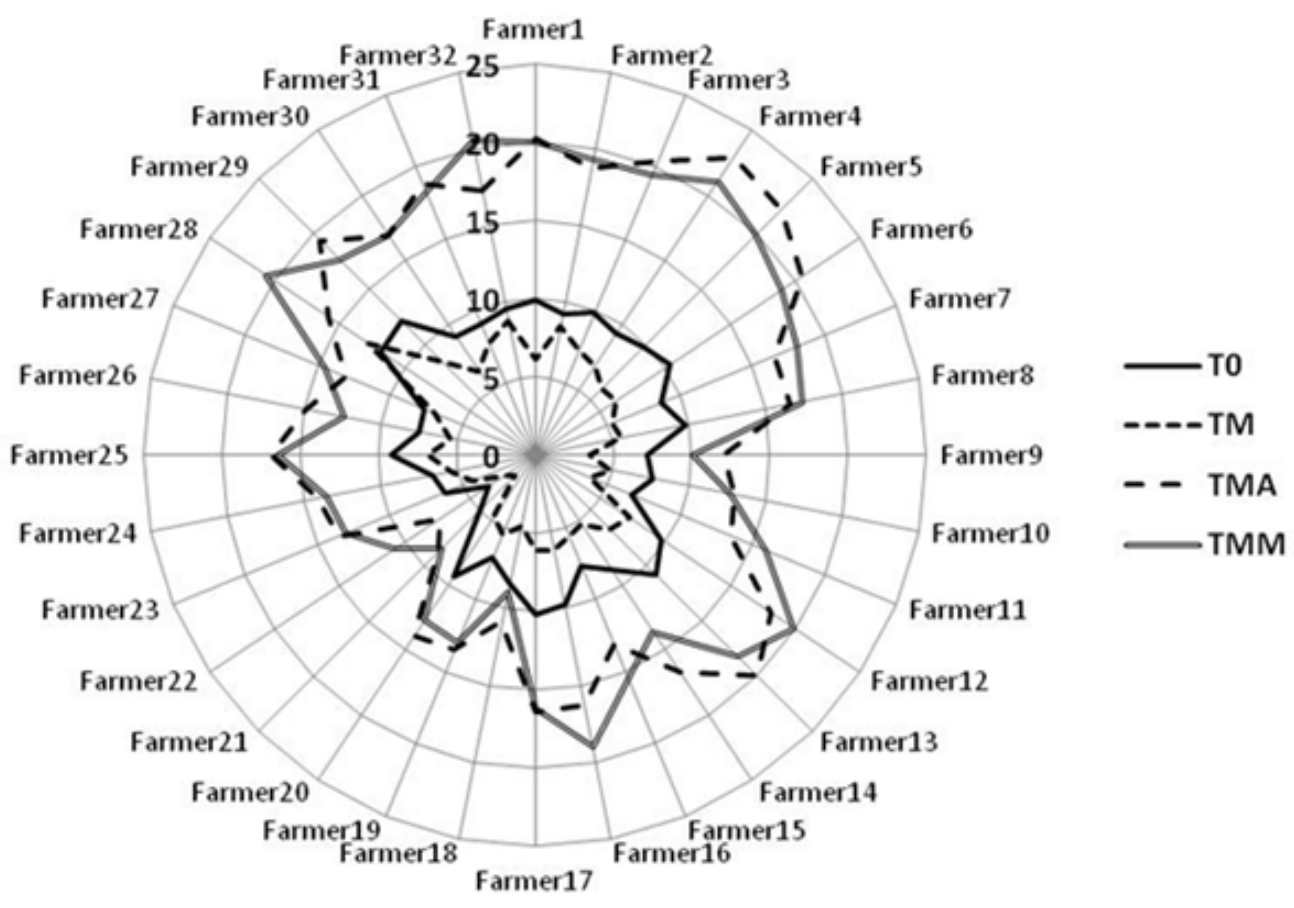

Figure 2: Effect of yam based-cropping systems on yam yield in the 2005 cropping season differed significantly by farmer for the same treatments.

Legend: T0 (control 1): 1-year fallow - yam rotation; TM (control 2): maize with chemical fertilizers - yam rotation; TMA: A. histrix /maize with chemical fertilizers intercropping - yam rotation; TMM: M. pruriens /maize with chemical fertilizers intercropping - yam rotation.

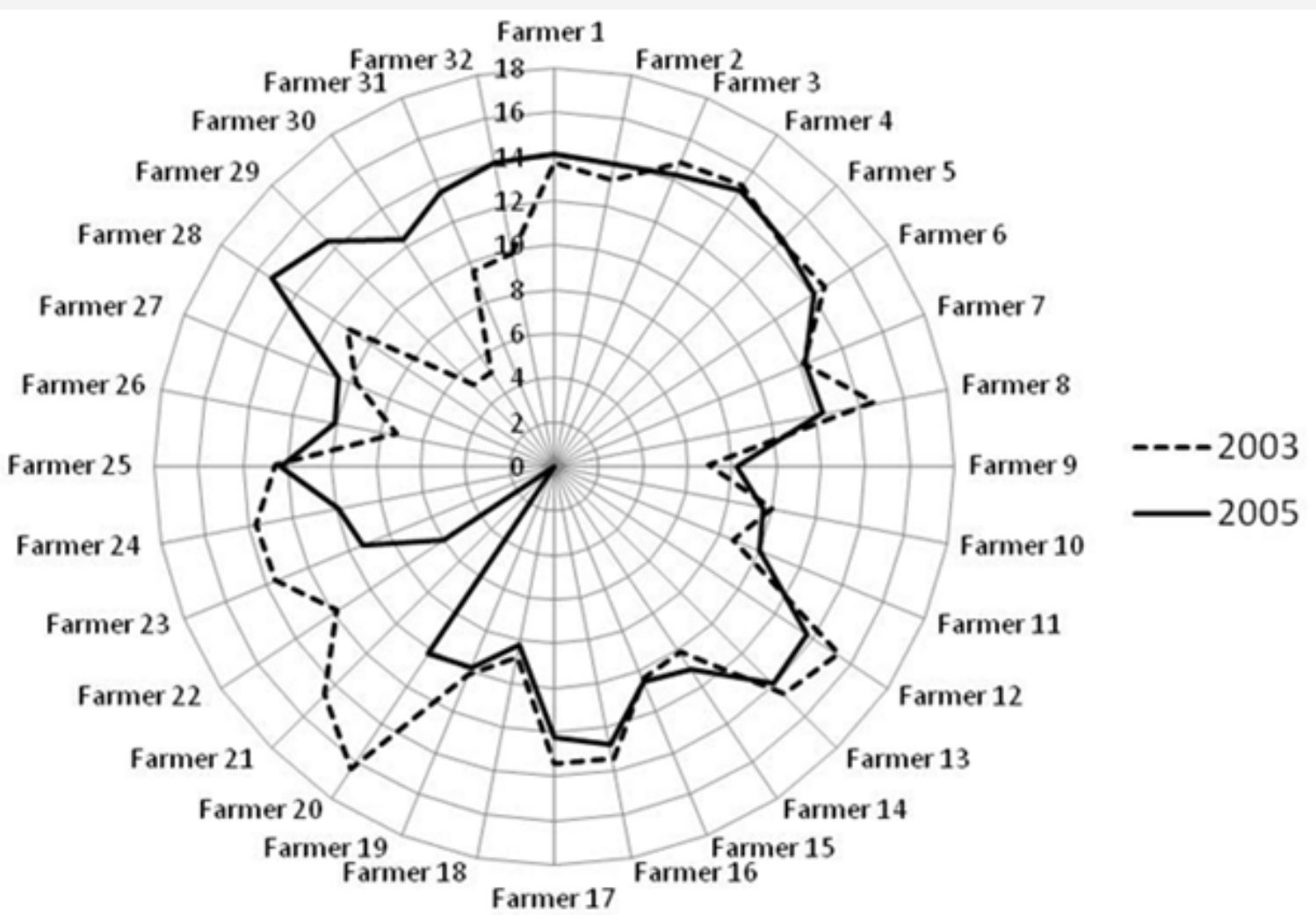

Figure 3: Effect of yam based-cropping systems on yam yield differed significantly by farmer for the same treatments from one year to another. 
Table 1: Design of yam-based cropping systems with herbaceous legumes, maize, short fallow and chemical fertilizers in the farmer-managed experiment: 2002-2003 and 2004-2005 cropping seasons, 32 farmers, four village sites (Miniffi, Gomè, Gbanlin and Akpéro), Benin.

\begin{tabular}{|c|c|c|c|c|}
\hline Treatments & Year 1 (2002) & $\begin{array}{l}\text { Year } 2 \\
(2003)\end{array}$ & Year 3 (2004) & $\begin{array}{l}\text { Year } 4 \\
(2005)\end{array}$ \\
\hline $\begin{array}{l}\text { T0 (control 1), 1-year } \\
\text { fallow - yam rotation }\end{array}$ & Fallow of A. gayanus & Yam & Fallow of A. gayanus & Yam \\
\hline $\begin{array}{l}\mathrm{TM}(\text { control } 2), \text { maize - } \\
\text { yam rotation }\end{array}$ & $\begin{array}{c}\text { Maize+ } \mathrm{N}_{14} \mathrm{P}_{23} \mathrm{~K}_{14}+\text { Urea: } 100 \mathrm{~kg} \mathrm{ha}^{-1} \mathrm{NPK} \\
\text { fertilizer }(14 \% \mathrm{~N}, 10 \% \mathrm{P}, 11.7 \% \mathrm{~K})+50 \mathrm{~kg} \mathrm{ha}^{-1} \\
\text { urea }(46 \% \mathrm{~N})\end{array}$ & Yam & $\begin{array}{c}\text { Maize }+\mathrm{N}_{14} \mathrm{P}_{23} \mathrm{~K}_{14}+\text { Urea: } 100 \mathrm{~kg} \mathrm{ha}^{-1} \mathrm{NPK} \\
\text { fertilizer }(14 \% \mathrm{~N}, 10 \% \mathrm{P}, 11.7 \% \mathrm{~K})+50 \mathrm{~kg} \\
\text { ha }^{-1} \text { urea }(46 \% \mathrm{~N})\end{array}$ & Yam \\
\hline $\begin{array}{l}\text { TMA (A. histrix / maize } \\
\text { intercropping - yam } \\
\text { rotation) }\end{array}$ & $\begin{array}{l}\text { A. histrix /maize intercropping }+\mathrm{N}_{14} \mathrm{P}_{23} \mathrm{~K}_{14}+ \\
\text { Urea }\end{array}$ & Yam & $\begin{array}{l}\text { A. histrix /maize intercropping }+\mathrm{N}_{14} \mathrm{P}_{23} \mathrm{~K}_{14} \\
+ \text { + Urea }\end{array}$ & Yam \\
\hline $\begin{array}{l}\text { TMM (M. pruriens / maize } \\
\text { intercropping - yam } \\
\text { rotation) }\end{array}$ & $\begin{array}{l}\text { M. pruriens /maize intercropping }+\mathrm{N}_{14} \mathrm{P}_{23} \mathrm{~K}_{14} \\
+ \text { Urea }\end{array}$ & Yam & $\begin{array}{l}\text { M. pruriens / maize intercropping + } \\
\qquad \mathrm{N}_{14} \mathrm{P}_{23} \mathrm{~K}_{14}+\text { Urea }\end{array}$ & Yam \\
\hline
\end{tabular}

Plot sizes: $10 \times 10 \mathrm{~m}$; Harvest plot size: $5 \times 5$ m; Number of farmers per site: 8; Yam variety tested: "Kokoro" (late maturing Dioscorea cayennensis subsp. rotundata; Number of treatments: 4 ; Number of replications: 4 .

\section{Conclusion}

The effects of treatments on yam yields differed significantly for the different farmers within a site, and different sites and improved the soil fertility. Yam has a poor response to mineral fertilizer applications. The heterogeneity of results should be related to the smallholders' individual effects and practices. Collaborations between farmers, research, development and extension structures should be favored to support the development and dissemination of innovations [12,13] (Tables 2\&3).

Table 2: Yam and maize yields as affected by the legumes/maize and chemical fertilizers - yam rotations (TMA: Aeschynomene histrix intercropped with maize-yam rotation; TMM: Mucuna pruriens intercropped with maize-yam rotation) versus the two control rotations (T0 control 1: 1-year Andropogon fallow-yam rotation; TM control 2: maize with chemical fertilizers-yam rotation) (4 sites, 32 farmers, Benin).

\begin{tabular}{|c|c|c|c|c|}
\hline \multirow{2}{*}{ Treatment } & \multicolumn{2}{|c|}{ Maize yield DM (t ha-1 } & \multicolumn{2}{|c|}{${\text { Yam yield DM }\left(\mathbf{t ~ h a}^{-1}\right)}^{\mathbf{1}}$. } \\
\cline { 2 - 5 } & $\mathbf{2 0 0 2}$ & $\mathbf{2 0 0 4}$ & $\mathbf{2 0 0 3}$ & $4.3 \mathrm{~b}$ \\
\hline T0 & - & - & $3.1 \mathrm{~b}$ & $3.0 \mathrm{c}$ \\
\hline TM & $1.9 \mathrm{a}$ & $1.7 \mathrm{a}$ & $7.2 \mathrm{a}$ & $8.0 \mathrm{a}$ \\
\hline TMA & $1.9 \mathrm{a}$ & $1.5 \mathrm{~b}$ & $7.3 \mathrm{a}$ & $8.0 \mathrm{a}$ \\
\hline TMM & $1.8 \mathrm{~b}$ & $1.4 \mathrm{c}$ & 0.51 & 0.55 \\
\hline LSD 5\% & 0.05 & 0.04 & 2.2 & 2.7 \\
\hline SD & 0.16 & 0.13 & & \\
\hline
\end{tabular}

DM: dry matter

Means with the same letter within column are not significantly different $(p>0.05)$.

Table 3: Soil characteristics at the end of the experiment (December 2005), 0-10 and 10-20 cm layers, four yam-based cropping systems (fallow of Andropogon gayanus, maize stover, herbaceous legumes of $A$. histrix and $M$. pruriens var utilis intercrops with chemical fertilizers), 32 farmers, four village sites, Benin (all sites confounded).

\begin{tabular}{|c|c|c|c|c|c|c|}
\hline Soil Characteristics & Depth & T0 & TM & TMA & TMM & LSD \\
\hline \multirow{2}{*}{ Clay\% } & $0-10 \mathrm{~cm}$ & $5.821 c$ & $5.519 d$ & $5.944 \mathrm{~b}$ & $5.959 a$ & 0.111 \\
\hline & $10-20 \mathrm{~cm}$ & $5.928 c$ & $5.611 d$ & $6.006 \mathrm{~b}$ & $6.054 \mathrm{a}$ & 0.124 \\
\hline \multirow{2}{*}{ Silt $\%$} & $0-10 \mathrm{~cm}$ & $9.546 a$ & $9.678 \mathrm{a}$ & $9.522 \mathrm{a}$ & $9.530 \mathrm{a}$ & ns \\
\hline & $10-20 \mathrm{~cm}$ & $9.714 \mathrm{a}$ & $9.807 a$ & $9.670 \mathrm{a}$ & $9.645 \mathrm{a}$ & ns \\
\hline \multirow{2}{*}{ Sand $\%$} & $0-10 \mathrm{~cm}$ & $84.628 a$ & $84.802 \mathrm{a}$ & $84.534 \mathrm{a}$ & $84,511 \mathrm{a}$ & ns \\
\hline & $10-20 \mathrm{~cm}$ & $84.357 a$ & $84.584 a$ & $84.324 a$ & $84.301 \mathrm{a}$ & ns \\
\hline \multirow{2}{*}{$\mathrm{C} \%$} & $0-10 \mathrm{~cm}$ & $0.766 \mathrm{~b}$ & $0,764 b$ & $0.818 \mathrm{~b}$ & $0.869 a$ & 0.037 \\
\hline & $10-20 \mathrm{~cm}$ & $0.723 b$ & $0.703 \mathrm{~b}$ & $0.780 \mathrm{a}$ & $0.827 \mathrm{a}$ & 0.033 \\
\hline \multirow{2}{*}{ N \% } & $0-10 \mathrm{~cm}$ & $0.064 \mathrm{~d}$ & $0.076 \mathrm{c}$ & $0.086 \mathrm{~b}$ & $0.095 a$ & 0.003 \\
\hline & $10-20 \mathrm{~cm}$ & $0.066 \mathrm{c}$ & $0.085 b$ & $0.094 \mathrm{a}$ & $0,099 a$ & 0.004 \\
\hline \multirow{2}{*}{ C: $N$} & $0-10 \mathrm{~cm}$ & $11.947 \mathrm{a}$ & $10.087 \mathrm{~b}$ & $9.551 \mathrm{c}$ & $9.032 c$ & 0.272 \\
\hline & $10-20 \mathrm{~cm}$ & $11.109 a$ & $8.309 b$ & $8.319 \mathrm{~b}$ & $8.343 b$ & 0.211 \\
\hline \multirow{2}{*}{ MO\% } & $0-10 \mathrm{~cm}$ & $1.317 \mathrm{~b}$ & $1.313 \mathrm{~b}$ & $1,408 \mathrm{a}$ & $1.495 \mathrm{a}$ & 0.063 \\
\hline & $10-20 \mathrm{~cm}$ & $1.244 \mathrm{c}$ & $1.209 \mathrm{c}$ & $1.342 \mathrm{~b}$ & $1.422 \mathrm{a}$ & 0.057 \\
\hline
\end{tabular}




\begin{tabular}{|c|c|c|c|c|c|c|}
\hline \multirow{2}{*}{$\mathrm{P}$ - Bray I $\left(\mathrm{mg} \mathrm{kg}^{-1}\right)$} & $0-10 \mathrm{~cm}$ & $10.210 \mathrm{c}$ & $11.840 \mathrm{~b}$ & $13.430 \mathrm{a}$ & $14.346 \mathrm{a}$ & 1.126 \\
\cline { 2 - 7 } & $10-20 \mathrm{~cm}$ & $8.750 \mathrm{c}$ & $10.660 \mathrm{~b}$ & $11.410 \mathrm{ab}$ & $12.290 \mathrm{a}$ & 1.217 \\
\hline \multirow{3}{*}{$\mathrm{K}^{+} \mathrm{cmol} \mathrm{kg}^{-1}$} & $0-10 \mathrm{~cm}$ & $0.331 \mathrm{~d}$ & $0.424 \mathrm{c}$ & $0.495 \mathrm{~b}$ & $0.536 \mathrm{a}$ & 0.026 \\
\cline { 2 - 7 } & $10-20 \mathrm{~cm}$ & $0.266 \mathrm{~d}$ & $0.330 \mathrm{c}$ & $0,409 \mathrm{~b}$ & $0.453 \mathrm{a}$ & 0.028 \\
\hline \multirow{2}{*}{$\mathrm{PH}$ water } & $0-10 \mathrm{~cm}$ & $6.063 \mathrm{c}$ & $6.688 \mathrm{~b}$ & $7.129 \mathrm{a}$ & $7.031 \mathrm{a}$ & 0.055 \\
\cline { 2 - 7 } & $10-20 \mathrm{~cm}$ & $6.060 \mathrm{c}$ & $6.680 \mathrm{~b}$ & $7.144 \mathrm{a}$ & $6.984 \mathrm{a}$ & 0.053 \\
\hline
\end{tabular}

Means with the same letter within row are not significantly different $(p>0.05)$

Legend: $\mathrm{C} \%$ : soil carbon concentration; $\mathrm{N} \%$ : soil nitrogen concentration; $\mathrm{OM} \%(=1.72 \times \mathrm{C} \%)$ : soil organic matter content; $\mathrm{C}$ : $\mathrm{N}$ : Index of biodegradability or ratio of soil carbon to nitrogen; P. ass. Bray $\left(\mathrm{mg} \mathrm{kg}^{-1}\right)$ : soil phosphorus; $\mathrm{K}^{+} \mathrm{cmol} \mathrm{kg}^{-1}$ : soil potassium; LSD: Least square difference at $5 \%$; SD: Standard deviation

T0 (control 1): 1-year fallow - yam rotation; TM (control 2): maize with chemical fertilizers - yam rotation; TMA: A. histrix /maize with chemical fertilizers intercropping - yam rotation; TMM: M. pruriens /maize with chemical fertilizers intercropping - yam rotation;

LSD: Least square difference at $5 \%$; ns: no significant data are the means.

Source: Maliki et al. (2016)

\section{Acknowledgement}

The authors express their sincere appreciation and thanks for the Food and Agriculture Organization of the United Nations (FAO) and to farmers who freely agreed to participate in trials and make part of their fields available for the research.

\section{Conflict of Interest}

The authors declare that there is no financial interest or conflict of interest regarding the publication of this paper.

\section{References}

1. FAOSTAT ( 2011) Crop data.

2. Diby LN, Hgaza VK, Tie TB, ASSA A, Carsky R, et al. (2009) Productivity of yams (Dioscorea spp.) as affected by soil fertility. J Anim Plant Sci 5(2): 494-506.

3. Adjei Nsiah S, Kuyper TW, Leeuwis C Abekoe MK, Giller KE (2007) Evaluating sustainable and profitable cropping sequences with cassava and four legume crops: Effects on soil fertility and maize yields in the forest/savannah transitional agro-ecological zone of Ghana. Field Crop Res 103: 87-97.

4. Sodjadan PK, Toukourou AM, Carsky RJ, Vernier P (2005) Effets des précédentes plantes de couverture sur la production de l'igname en zone de savane au Bénin et au Togo. AJRTC 6(1): 34-40.

5. Srivastava A, Gaiser T (2010) Simulating biomass accumulation and yield of yam (Dioscorea alata) in the Upper Ouémé Basin (Benin Republic) I. Compilation of physiological parameters and calibration at the field scale. Field Crop Res 116: 23-29.

6. Gbedolo YM (1986) Factors limiting yam production in Benin. In ER Terry, et al. (ed.) Tropical root crops: Root crops and the African food crisis. Proc Trienn Symp Int Soc Trop Root Crops, $3^{\text {rd }}$, Owerri, Nigeria, pp. 57-60.
7. Ennin SA, Isaaka RN, Acheampong PP, Numafo M, Owusu Danquah E (2014) Mechanization, fertilization and staking options for environmentally sound yam production. African Journal Agricultural Research 9(29): 2222-30.

8. Cornet D Amadji F, Dossou R, Maliki R, Vernier P (2005) Intérêts des légumineuses herbacées pour une production durable d'igname en Afrique de l'Ouest, in Ozier Lafontaine H, Ed., Proceedings of the $41^{\text {th }}$ international meeting of the CFCS, Le Gosier, Guadeloupe.

9. Djokoto RK, Stephens S (1961) Thirty long-term fertilizer experiments under continuous cropping in Ghana, in crop yield and responses to fertilizers and manures. EJ Exp Agri (29): 181-195.

10. Diby LN, Carsky R, Assa A, Tra TB, Girardin O, et al. (2004) Understanding soil factors limiting the potential yield of yam (Dioscorea spp.). In Proceedings of the $4^{\text {th }}$ International Crop Science Congress, Brisbane Australia.

11. Agossou V, Igué M (2002) Caractérisation des sols des sites de recherche développement du CRA-Centre: classification dans la base de référence mondiale et actualisation de leur niveau de dégradation, Atelier scientifique Centre, Bénin.

12. Chapman EA (1965) Some investigations into factors limiting yields of White Lisbon yams (Dioscorea alata) under Trinidad conditions. Trop Agric 42: 145-151.

13. O Sullivan JN (2010) Yam nutrition: nutrient disorders and soil fertility management. Australian Centre for International Agricultural Research (ACIAR).

14. Maliki R, Sinsin B, Floquet A, Cornet D, Malezieux E, Vernier P (2016) Dry Matter Production, Nutrient Cycled and Removed, and Soil Fertility Changes in Yam-Based Cropping Systems with Herbaceous Legumes in the Guinea-Sudan Zone of Benin. Hindawi Publishing Corporation, Scientifica, 12 pages. 